Elsevier Editorial System(tm) for Journal of Hydrology

Manuscript Draft

Manuscript Number:

Title: AMMA-CATCH studies in the Sahelian region of West-Africa: an overview.

Article Type: Special Issue; Lebel AMMA

Keywords: West Africa, Sahel, Land Surface Processes, Continental Scale Experiments, Water Resources

Corresponding Author: Dr. T. F. Lebel, PhD

Corresponding Author's Institution: UMR 5564

First Author: T. F. Lebel, PhD

Order of Authors: T. F. Lebel, PhD; Bernard Cappelaere, PhD; Sylvie Galle, PhD; Niall Hanan, PhD; Laurent Kergoat, PhD; Samuel Levis, PhD; Baxter Vieux, PhD; Luc Descroix, PhD; Marielle Gosset, PhD; Eric Mougin, PhD; Christophe Peugeot, PhD; Luc Seguis, PhD 
Konstantine P. Georgakakos, Sc.D.

Editor-in-Chief, Journal of Hydrology

Hydrologic Research Center

12780 High Bluff Drive, Suite 250

San Diego, CA 92130, USA

Grenoble, $3^{\text {rd }}$ December 2008

Dear Dr Georgakakos,

You will find herewith the manuscript of the overview paper for the AMMA-CATCH special issue, entitled "AMMA-CATCH studies in the Sahelian region of West-Africa: an overview", by T. Lebel et al..

The main objectives of this paper are: (i) to present the rationale for maintaining a long term hydrometeorological observing system in West Africa ; (ii) to review the state of the art regarding our knowledge on the land-atmosphere interactions in this region and the main scientific questions to address in order to improve our understanding of these interactions; (iii) to present the observational strategy of this long term observing system; and finally iv) the paper describes the scope and content of the special issue. As present, 18 papers are accepted for publication in the special issue, 6 are in final form, 12 others were accepted pending minor of moderate revision (written in green in the scope and content section and in the list of references); one is still undergoing revision of the re-submitted version (written in red in the scope and content section). Given the time needed for reviewing a paper and in order not to delay the final publication of the special issue, this overview paper is submitted now, since it is considered that the papers accepted pending minor of moderate revision, will indeed be included in the special issue.

We thank you very much for considering this manuscript for the special issue.

With best regards, 


\section{AMMA-CATCH studies in the Sahelian region of West-Africa: an overview.}

\author{
Thierry Lebel $^{1}$, Bernard Cappelaere ${ }^{2}$, Sylvie Galle ${ }^{1}$, Niall Hanan $^{3}$, Laurent Kergoat ${ }^{4}$, Samuel Levis ${ }^{5}$, \\ Baxter Vieux ${ }^{6}$, Luc Descroix ${ }^{1}$, Marielle Gosset ${ }^{1}$, Eric Mougin ${ }^{4}$, Christophe Peugeot ${ }^{2}$, Luc Seguis ${ }^{2}$ \\ ${ }^{1}$ LTHE, IRD, BP 53, 38041 Grenoble Cedex 9, France \\ ${ }^{2}$ HSM, IRD, BP 64501, 34394 Montpellier cedex 5, France \\ ${ }^{3}$ Natural Resource Ecology Laboratory, Colorado State University, Fort Collins, CO 80523, U.S.A. \\ ${ }^{4}$ CESBIO, CNRS, Toulouse, France \\ ${ }^{\mathbf{5}}$ National Center for Atmospheric Research, Boulder, CO, USA \\ ${ }^{\mathbf{6}}$ School of Civil Engineering and Environmental Science, University of Oklahoma, Norman, OK, USA
} Submitted for publication in the AMMA-CATCH special issue of Journal of Hydrology Unreviewed Version - October 2008 24 E-mail:thierry.lebel@hmg.inpg.fr 
5 Thierry Lebel, Bernard Cappelaere, Sylvie Galle, Niall P. Hanan, Laurent Kergoat, Samuel Levis, Baxter Vieux,

\begin{abstract}
.
The African Monsoon Multidiciplinary Analysis (AMMA) is an international and interdisciplinary experiment designed to investigate the interactions between atmospheric, oceanic and terrestrial systems and their joint controls on tropical monsoon dynamics in West Africa. This special issue reports results from a group of AMMA studies regrouped in the component "Couplage de l'Atmosphère Tropicale et du Cycle Hydrologique" (CATCH). AMMA-CATCH studies focus on measuring and understanding land surface properties and processes in West Africa, the role of terrestrial systems in altering boundary layer dynamics, and thus the potential that surface hydrology and biology, and human land use practices, may directly or indirectly affect monsoon dynamics and rainfall in the region. AMMA-CATCH studies focus on three intensively instrumented mesoscale sites in Mali, Niger and Benin that sample across the 100-1300 mm/annum rainfall gradient of the Sahel, Sudan and NorthGuinean bioclimatic zones. Studies report on i) surface-boundary layer interactions that may influence atmospheric convergence and convective processes and thus rainfall type, timing and amount; ii) vegetation dynamics at seasonal to decadal time-scales that may respond to, and alter, atmospheric processes; iii) surface-atmosphere fluxes of heat, water and carbon dioxide that directly influence the atmosphere; iv) soil moisture variability in space and time that provide the proximate control on vegetation activity, evapotranspiration and energy balance; and v) local and mesoscale modeling of hydrology and land surface-atmosphere exchanges to assess their role in the hydrological, atmospheric and rainfall dynamics of West Africa. The AMMA-CATCH research reported in this issue will be extended in future years as measurements and analysis continue and are concluded within the context of both CATCH and the wider AMMA study. This body of research will contribute to an improved understanding of the functioning of the coupled West African system, and enhance our ability to model and predict rainfall, vegetation and biogeochemical dynamics across time-scales (day, year, decade, century), and in response to changing climate and land use. Such information is vital for policy makers and managers in planning for future economic development, sustainability and livelihoods of the growing populations of the region.
\end{abstract}

Key Words: West Africa, Sahel, Land Surface Processes, Continental Scale Experiments, Water Resources 


\section{Introduction}

2 The generalised drought that struck West Africa during the 1970s and 1980s was one of the 3 most significant regional scale climatic events of the $20^{\text {th }}$ century (AMMA ISSC, 2005). The

Figure 1 about here

The consequences of this drought were devastating due to both its spatial extent and its continuity in time (Fig. 2): every year of the period 1970-1988 was in deficit in the Sahel (the region south of the Sahara desert where mean annual precipitation is $100-700 \mathrm{~mm}$ ), and most years were in deficit over the Soudanian region to the South (between the Guinea Gulf and the Sahel). The spatial and temporal continuity of this dry anomaly and of the preceding wet anomaly are all the more remarkable when compared to rainfall time series of other tropical regions, where runs of dry years are usually limited to 4-5 years (Nicholson, 2000).

\section{Figure 2 about here}

Despite unfavourable climatic and environmental conditions, the cultivated Sahel is one of the most densely populated areas in West Africa (Fig.3). The drought has thus devastating effects on the population, through famines, migrations, and low economic growth, underlying its vulnerability to climatic fluctuations (see e.g. Davidson et al., 2003; ECOWAS-SWAC, 2006; Stige et al., 2006).

\section{Figure 3 about here}

In the last two decades (1990-present) a return to wetter conditions was observed in much of West Africa, but below average rainfall continued almost unabated in the Sahel region, at least until the end of the 1990s (as described in Lebel and Ali, this issue, the situation changed 
1 somewhat later on). This is a confirmation of the fact already mentioned in previous works 2 (see e.g., Janicot,1992; Nicholson, 1980) that, while the climate of the whole of West Africa 3 is under the control of the West African Monsoon (WAM), the Soudanian and Sahelian 4 regions are not systematically, or directly, coupled in terms of annual rainfall fluctuations. The possible role of changing surface conditions in this pattern of rainfall variability has long been questioned, starting with the seminal paper of Charney (1975).

The issue of changing surface conditions is especially acute in a region which has to support one of the fastest population growths in the world, with a growth rate now above $3 \% . \mathrm{yr}^{-1}$ (Guengant and Banoin, 2003). Rapidly increasing needs for food crops and firewood have led to extensive forest clearing and degradation, and the densely populated southern band of the Sahel ( 400-700 mm of annual rainfall), has consequently undergone the transformation of an essentially natural, savanna landscape before the first drought of the 1970s, into the highly modified environment of today, with considerably reduced vegetation cover and generalized soil degradation. Charney's hypothesis was that vegetation degradation over the Sahel might induce a long term inhibiting feedback on rainfall. This assumption has been tested in numerous modelling studies. In the first experiments carried out with Global Circulation Models (GCMs), Laval and Picon (1986) and Xue and Shukla (1993), for example, diagnosed that the Sahelian climate was sensitive to changes in the surface roughness and albedo. Ensuing simulations paid greater attention to the role of the vegetation and of the water cycle: Polcher (1995), Douville et al. (2001), Douville (2002), Koster et al. (2004), Taylor et al., (2007), among others, all showed that soil moisture is a significant factor influencing the dynamics of the tropical monsoon systems, especially in West Africa where recycling processes play an important role (Fig. 4).

Diagnostic studies also show that the interannual variability of specific patterns of deep soil wetness and moist static energy south of the Sahel during the pre-monsoon onset months are significantly correlated with the recent interannual variability of Sahelian rainfall (Fontaine et al., 1999; Philippon and Fontaine, 2002). Despite all these converging results that the WAM 
1 does show sensitivity to feedback effects associated with land use / land cover changes, these

2 effects are still very poorly understood and inadequately represented in GCMs. This creates

3 much variation in projections on future rainfall trends, and call for improvement in the

4 documentation of the underlying processes through field research programs and long term monitoring strategies. The African Monsoon Multidisciplinary Analyses (AMMA), an initiative launched at the beginning of the millennium is rooted in this context (AMMA-ISSC, 2005; Redelsperger et al., 2006). AMMA-CATCH (CATCH stands for Couplage de l'Atmosphère Tropicale et du Cycle Hydrologique) is the long term monitoring component of AMMA, focused on documenting the simultaneous variability of rainfall, continental surface conditions and WAM dynamics. While AMMA-CATCH deals with both the Sahelian and the Soudanian sub-regions of West-Africa, the focus of this special issue is on the Sahel, for this is where specific monitoring sites have operated for the longest time (see the description of the observation strategy below).

\section{A brief review of biosphere-atmosphere coupling and the Sahelian climate} made at documenting comprehensively over a whole seasonal cycle the various variables and processes that control the land surface - atmosphere linkages in this semi-arid environment. An ensemble of 67 individual investigations deployed specific instruments for periods ranging from a few weeks to two years within a $1^{\circ} \times 1^{\circ}$ area $\left(13^{\circ} \mathrm{N}-14^{\circ} \mathrm{N} ; 2^{\circ} \mathrm{E}-3^{\circ} \mathrm{E}\right)$ in the region of Niamey (South-West Niger).

The data collected during HAPEX-Sahel and the ensuing studies (many of them were reported in the 1997 HAPEX-Sahel special issue of Journal of Hydrology, see Dolman et al., $1997 \mathrm{~b}$, for a summary) confirmed previous observations and some intuitive assumptions preexisting the experiment. They also led to new findings and raised new questions, thus forming the single most significant contribution to the science of land surface - atmosphere interactions in the Sahel at that time.

The intuitive assumptions that were confirmed were essentially: 
- the temporal distribution of rainfall is as important as total seasonal rainfall for water balance control (Desconnets et al., 1997; Peugeot et al., 1997); this observation made on small catchments was confirmed for larger catchments in later studies, as illustrated in Fig. 5 showing from model results that for roughly the same annual rainfall, the amount of deep infiltration recharging the aquifer beneath a $5,000 \mathrm{~km}^{2}$ catchment was 4 times larger in 2004 than in 2005.

- Changing vegetation patterns led to a changing of the regional water balance (Gash et al., 1997; Gaze et al., 1997; Kabat et al., 1997).

- At the seasonal scale, rainfall is the primary driver of vegetation growth and annual rainfall patterns are mirrored in crop yield patterns as well as in vegetation index patterns from satellite imagery.

- There is a close linkage between carbon and water (Moncrieff et al., 1997).

\section{Figure 5 about here}

The specific data collected during HAPEX-Sahel also led to less intuitive results, including (see Dolman et al.,1997b and Nicholson, 2000, for a more systematic review):

- Interannual variations of observed rainfall are associated with the fluctuations of the number of rain events rather than with the fluctuations of their intensity (Le Barbé and Lebel, 1997; Le Barbé et al., 2002).

- From a multi-year monitoring that followed HAPEX-Sahel, Balme et al (2005) also found that the total seasonal rainfall does not correlate well with the length of the rainy season, a result enforcing the idea of Nicholson (2000) that the position of the ITCZ is not a major factor in determining seasonal rainfall totals.

- The spatial pattern of annual rainfall is rather patchy, with local gradients that can reach $30 \mathrm{~mm} / \mathrm{km}$ in any direction, to be compared to the average $1 \mathrm{~mm} / \mathrm{km}$ South to North negative gradient, characterizing the Sahelian climate (Lebel et al., 1997).

- More than vegetation, it is soil crusting (Casenave and Valentin, 1992) that determines the spatial pattern of runoff areas and infiltration areas (Peugeot et al., 1997). For 
hydrological modeling the correct specification of crusted and non-crusted areas is thus very important (Braud et al., 1997).

- Runoff at large scale is very small and more than $95 \%$ of the rainfall is recycled as evapotranspiration.

- In Mali and Niger, most small catchments nominally drained by the Niger river (at least on its left bank) are in fact endorheic, meaning that locally produced runoff does not reach the Niger river, but rather infiltrates in spreading areas or is collected into temporary pools, from which it infiltrates towards the aquifer or evaporates. The increased proportion of degraded (hence encrusted) areas has led to an increase of the local runoff coefficients and thus to an increased infiltration towards the aquifer, producing what has been termed "the Niamey paradox" (Leduc et al., 2001): despite lower rainfall since the 1970s, the level of the aquifer has been continuously raising in West Niger since the mid-1960s (Fig. 6).

- From the data collected by the flux stations installed in the region in 1991 and 1992 , Gash et al. (1997) and Kabat et al. (1997) suggested that the diurnal variations in evapotranspiration are dominated by soil evaporation. Nevertheless interlacing of bare soil and vegetated areas and their respective areal proportions are a key controlling factor for evaporation (Simioni et al., 2003).

- The same data also showed that a millet field is evaporating much less than a fallow composed of grass and shrubs.

- Dolman et al. (1997a) and Said et al. (1997) argued that vegetation driven changes in Boundary Layer response may not always be visible due to the stronger effects of large scale advections.

- The strong local gradients of annual rainfall were shown to be sometime related to a persistence phenomenon, whereby an initial gradient associated with an earlier convective event maintained itself through the whole rainy season, with rainfall at the "wet" station being systematically larger than rainfall at the "dry" station for ensuing rain events (Taylor and Lebel, 1998).

Other results that are not directly relevant to this special issue are related to the role of 
1 aerosols (Goutorbe et al., 1997b) and their effects on radiation divergence resulting from the

2 high aerosol loading in the HAPEX-Sahel region.

3 Many of the above results deduced from HAPEX-Sahel observations are coherent with our 4 general understanding of the changes that affect the water cycle and the climate of the region.

Figure 6 about here

As argued by Dolman et al. (1997b), the large scale transformation of fallow savanna into millet fields could have two potentially opposite effects on rainfall: i) by decreasing the evapotranspiration it could act as a rainfall reduction factor; ii) by increasing the sensible heat fluxes it could favour an increase of precipitation. There are also dynamical factors to consider since changing the pattern and roughness of vegetation also has potential effect on rainfall triggering. The balance between mesoscale processes that are the primary rainfall producing factors, and local-scale features that are important drivers in producing regional variability, has been investigated through numerous modelling studies in the years following the HAPEX-Sahel field campaigns (see e.g. Xue and Shukla, 1993; Rowell et al., 1995; , Eltahir and Gong, 1996; Zeng et al., 1999). However, rather than converging towards a well established vision of the respective roles of land surface processes and the SSTs in the interannual to decadal variability of the Sahelian rainfall, these studies serve primarily to highlight the remaining uncertainties. The problem with GCM simulations is that they cannot realistically simulate the meso to local scale factors, such as orography, which is of limited amplitude in West Africa but can still play a role in convection triggering and organisation. 
1 Conversely, simulations with simple models that show that surface hydrology can lock the 2 system into persistent drought mode, fail to consider how large scale forcings influence local and regional conditions. As pointed out by Nicholson (2000), the link between boundary layer processes and interannual rainfall has yet to be understood, and this might well be the "most important area of future research on land-atmosphere interactions in the Sahel". Similarly Dolman et al. (1997b) insist on "the complicated balance between surface driven variation and large scale flow pattern", which means that improving our understanding of the interactions between climate dynamics and land surface variability/changes requires documentation of contrasting large scale synoptic situations. These situations do not occur every year, since they are associated with global-scale forcing conditions that have multiannual to decadal time-scale temporal characteristics (for example the El Nino Southern Oscillation, ENSO). An illustration of this multi-year problematics is given in Fig. 7, showing for the AMMA-CATCH site of Niger the relationship between the annual rainfall $\left(R_{A}\right)$ and the number of mesoscale rain events recorded each year $(N)$. These mesoscale rain events account for about $90 \%$ of the total annual rainfall. The determination coefficient of the linear correlation between the annual rainfall and the number of mesoscale events is $0.50(0.57$ when replacing the total annual rainfall by the annual rain falling only during these mesoscale rain events, $\left.R_{A}^{*}\right)$. At the same time the coefficient of determination for the linear correlation between annual rainfall and the mean annual event rainfall $\left(R_{E}\right)$ is 0.04 (unchanged when replacing the total annual rainfall by the annual rain falling only during these mesoscale rain events). Since $R_{A}^{*}=N \cdot R_{E}$, it is puzzling that the interannual fluctuations of $R_{A}{ }^{*}$ are explained only by those of $N$, displaying no correlation at all with those of $R_{E}$. At the same time, the variability of $N$ explains only half of the variability of $R_{A}^{*}$, which is food for thought regarding the predictability of the interannual rainfall variability in the Sahel.

\section{Figure 7 about here}

All this points to the necessity of a more systematic documentation of the interacting atmospheric and water cycle processes over several seasonal cycles in order to catch the diversity of situations controlling these interactions, the memory effects from one year to the next and the possible decadal-scale trends. This latter point is of particular concern. Indeed, as 
1 underlined by the Niamey paradox described above, the eco-climatic system is clearly in a non steady state -at least in some parts of the region - and it is thus of utmost importance to monitor what is happening during this transition phase that lasted several decades and may be continuing.

The shortcomings of the existing operational observing systems when it comes to documenting simultaneously the various components and scales of the interacting landatmosphere West African system stimulated the establishment of the CATCH long term observing system. This system was designed in 2001, with funding from the French Ministry of Research and IRD. The ensuing launch of the AMMA international program led to the integration of this observing system into the broader AMMA field program run over the years 2005-2007.

\section{Observational strategy}

\section{Three mesoscale sites sampling the eco-climatic gradient}

The AMMA-CATCH observing system is based on three mesoscale sites sampling the West-African eco-climatic gradient (Fig. 8). The larger scale picture is obtained through various non-CATCH specific observation networks (national raingauge networks, hydrological networks) and remote sensing imagery. Each of the mesoscale sites also includes super-sites and local intensive sites (Table 1) allowing for more detailed process studies and water balance estimation.

Figure 8 about here

The Gourma-Mali site is located in the Northern Sahel $\left(14.8^{\circ} \mathrm{N}\right.$ to $\left.17.3^{\circ} \mathrm{N}\right)$ with average annual rainfall decreasing from $400 \mathrm{~mm}$ in the South to $150 \mathrm{~mm}$ in the North (1990-2007 averages). It is a typical rangeland region, covered with semi-arid natural vegetation composed of annual grasses and a sparse tree layer. The South-West Niger site $\left(13^{\circ} \mathrm{N}\right.$ to $14^{\circ} \mathrm{N}$ ) is typical of the central Sahel conditions with average annual rainfall decreasing from $570 \mathrm{~mm}$ in the South to $470 \mathrm{~mm}$ in the North (1990-2007 averages), and a semi-arid vegetation now essentially composed of millet fields, fallows and tiger bush on the plateaux. 
1 The capital of Niger, Niamey, is located within this region, generating heavy demographic

2 pressure in its surroundings, including intensive agricultural usage and wood cutting for fuel-

3 wood purposes. The third site is the Ouémé catchment site in Benin $\left(9^{\circ} \mathrm{N}\right.$ to $\left.10.2^{\circ} \mathrm{N}\right)$, where

4 annual rainfall averages 1200 to $1300 \mathrm{~mm}$. The rainfall gradient is not North-South, as is typically the case for the two other sites but rather East to West. The natural vegetation is wooded savanna typical of Sudano-Guinean formations, with interspersed crops including maize and niébé.

Table 1. The AMMA-CATCH meso-sites.

\begin{tabular}{|c|c|c|c|}
\hline & Gourma Mali Site & SW Niger Site & Ouémé Catchment \\
\hline Position & $\begin{array}{c}\text { Mali; } 14.8^{\circ} \mathrm{N}-17.3^{\circ} \mathrm{N} ; 2^{\circ}-1^{\circ} \mathrm{W} \\
\mathbf{2 7 0 0 0} \mathbf{~ k m}^{\mathbf{2}}\end{array}$ & $\begin{array}{l}\text { Niger; } 13^{\circ} \mathrm{N}-14^{\circ} \mathrm{N} ; 1.6^{\circ} \mathrm{E}-3^{\circ} \mathrm{E} \\
16000 \mathbf{~ k m}^{2} \\
\text { Catchment in the North-East } \\
\text { of the site: } 5800 \mathrm{~km}^{2}\end{array}$ & $\begin{array}{c}\text { Bénin; } 9^{\circ} \mathrm{N}-10^{\circ} \mathrm{N} ; 1.5^{\circ} \mathrm{E}-3^{\circ} \mathrm{E} \\
\mathbf{1 4 2 0 0} \mathbf{~ k m}^{\mathbf{2}}\end{array}$ \\
\hline Period of activity & 1984- to date & 1990- to date & 1997- to date \\
\hline Description & $\begin{array}{l}\text { North Sahelian climate } \\
\text { (between isohyets } 400 ? \text { and } \\
100 \mathrm{~mm} \text { ). Semi-arid natural } \\
\text { vegetation composed of annual } \\
\text { grasses and a sparse tree layer. } \\
\text { Crops only present in the } \\
\text { southern part of the area. } 16 \\
\text { vegetation sites monitored } \\
\text { since } 1984 .\end{array}$ & $\begin{array}{l}\text { The survey of the "Niamey square } \\
\text { degree" started in 1990. Intensive } \\
\text { observations in 1991-92, } \\
\text { monitoring from } 1994 \text { to } 2002 \text {, } \\
\text { with more intensive activities } \\
\text { starting again in } 2003 \text {. } \\
\text { South Sahelian climate with semi- } \\
\text { arid vegetation and crops (millet, } \\
\text { fallows and Tiger bush,). Long } \\
\text { series of high resolution rain data } \\
\text { and groundwater levels. }\end{array}$ & $\begin{array}{l}\text { Densely instrumented catchment } \\
\text { with denser instrumentation on } \\
\text { sub-catchments (Donga, Aguima, } \\
\text { Ara). } \\
\text { Soudanian climate (different types } \\
\text { of rain systems) and Guinean } \\
\text { savanna vegetation. }\end{array}$ \\
\hline
\end{tabular}

\section{A long term monitoring effort}

The three meso-sites that comprise the AMMA-CATCH observing system were built in three independent phases. The Gourma site was initially focused on vegetation studies, with unique long-term monitoring of vegetation production and dynamics in 25 parcels distributed north-south on the 100-450 mm rainfall gradient since the mid 1980s. The major effort of the 1990s was on the Niger site, where intensive measurements during the Hapex-Sahel experiment gave birth to long term monitoring of the main components of the hydrological cycle on this site (rainfall, runoff, ground water). The instrumentation of the Ouémé site was installed at the end of the 1990s and was also initially focused on the hydrological cycle as a Soudanian counterpart of the Niger Sahelian site. Since the major challenge of studying the interactions between climate and vegetation cover requires a joint observation of the 
1 atmosphere, the surface conditions and the water cycle, it was decided at the beginning of the

22000 s to merge the three sites in a single project - CATCH. It took a few years to upgrade the

3 instrumentation of these three sites, especially regarding soil moisture and surface flux

4 measurements (see Mougin et al., this issue and Cappelaere et al., this issue). In 2005, the

5 Enhanced Observing Period (EOP) of AMMA started (Redelsperger et al., 2006). The

6 AMMA EOP (2005-2007; also referred to as AMMA-CATCH) is the second phase of the

7 project. For AMMA-CATCH the hydrometeorological instrumentation across the observing system was considerably strengthened, with increased of the radio-sounding frequency, temporary installation of C-band and X-band radar systems and profilers, and deployment of additional flux stations, including the Atmospheric Radiation Measurement (ARM) Mobile Facility (AMF) ARM mobile facility (Miller and Slingo, 2007). Following the EOP some instruments have been removed but core measurements will be maintained until 2010 at least and a few key instruments installed during the EOP will also continue to operate (flux and soil moisture stations, additional recording rain gauges). The results presented in this special issue are based on the data collected during the first two phases of AMMA-CATCH, covering 2001-2007, but in some cases extending earlier into the 1990s.

\section{Scope and content of the special issue}

This special issue reports some important results obtained from this unique experimental setup for the two Sahelian sites, those which have been in operation for the longest time. A more precise description of the specific environment and experimental setup of these two sites is given in Mougin et al. (this issue) for the Gourma site and in Cappelaere et al. (this issue) for the Niger site. A few papers also present the first results obtained for the Ouémé mesoscale site, thus providing an idea of the contrasting characteristics and processes in the Sahel and Soudano-Guinean region.

A particular interest of the two AMMA-CATCH Sahelian sites from the hydrologist's standpoint lies in the endorheic nature of their surface hydrology: catchments are limited to scales of only up to a few tens of square kilometres at most, and most include both highly runoff-prone and infiltration-prone surfaces. These properties, typical of many arid to semiarid areas, raise challenging questions and difficulties for field observation as well as 
1 modelling.

2 The West African droughts of the 1970s and 1980s caused widespread vegetation 3 degradation and loss of woody cover in the region and heightened concerns that 4 desertification, overgrazing and global climate change would inevitably lead to serious environmental problems for the foreseeable future. While vegetation degradation and loss of woody cover do indeed present serious challenges to the livelihoods of many West African communities, in some areas recovery of vegetation with recent returns to more average rainfall provides evidence that Sahelian ecosystems may be more resilient than previously thought (Anyamba and Tucker, 2005; Herrmann et al., 2005; Herrmann and Hutchinson, 2005; Nicholson, 2005; Olsson et al., 2005; Prince et al., 1998). Studies of vegetation dynamics in response to climate, grazing and human land use patterns are, therefore, vital for our understanding of the dynamics and resilience of Sahelian and Sudanian ecosystems.

This special issue presents a collection of the results obtained at this point from the various program components, covering both the physical and biological processes of interest. New field data of great quality contribute to the improvement of our understanding of this environment through a combination of data-driven analyses and modelling studies.

After a presentation of the specific scientific questions of and experimental setup on the two meso-sites (Cappelaere et al., this issue; Mougin et al., this issue), three framework papers present the key features of rainfall regime variability, land use changes and hydrology of the region over the past decades. After 30 years of generalised rainfall deficit over the whole Sahel, Lebel and Ali (this issue) observe that the central Sahel has been recording wetter conditions over the last decade, while the drought remain unabated in the Western Sahel. However, by comparison to the wet period 1950-1969, the rainfall regime of the Central Sahel - as analysed from a $5^{\circ} \times 5^{\circ}$ box - is still characterised by an earlier and less intense rainfall peak during the core of the rainy season, associated with a smaller number of rain events, which means an increased probability of intraseasonal droughts. Vegetation changes result from both the long lasting drought of the period 1970-2000 but also from increased anthropogenic pressure, as analysed by Hiermaux et al. (this issue, a) on a sample of 71 field sites sampled among the crop fields, fallows and rangelands in the Fakara region (Niger) monitored from 1994 to 2006. The overall trend in land use confirmed continuation of the historical increase of cropped area since the mid $20^{\text {th }}$ century, at an annual rate of $2.7 \%$ from 
11994 to 2006. This trend arises because of increases in the extent of permanently cropped

2 fields, and reductions in the duration of fallow in intermittently cultivated fields. Descroix et

3 al. (this issue) then discuss how rainfall regime modifications and the overexploitation of the

4 environment combined to cause changes in catchment water balance and sediment budget..

5 Runoff has been increasing in most Sahelian basins for 3 decades, despite a $20-25 \%$ decrease

6 in observed rainfall during the period of 1968-1995. On the contrary, in the Southern Sahel

7 and in regions of Sudanian climate, a 15\% reduction in rainfall has led to a larger relative

8 reduction in runoff and annual discharges. As a result, the large West African rivers, mainly

9 the Niger and the Senegal, have suffered a significant decrease in flows despite their

10 considerable extension into Sahelian areas because their discharges are mainly provided by 11 regions in the Sudanian climate.

The special issue then proceeds by presenting contributions in the four main domains that are essential for the understanding of the coupling between vegetation and the water cycle: i) meteorology, rainfall and boundary layer studies; ii) vegetation studies; iii) soil moisture; iv) hydrological processes and modelling.

\section{Regional Meteorology}

Guichard et al. (this issue) present a quantitative analysis of the pronounced seasonal and diurnal cycles of surface thermodynamics and radiative fluxes in the Northern Sahel, where pasture is the predominant land use. Based on data collected from 2002 to 2007 in the Malian Gourma, close to Agoufou, at $1.5^{\circ} \mathrm{W} 15.3^{\circ} \mathrm{N}$ and sounding data collected during the AMMA field campaign, the paper assesses how the strong dynamics associated with the transition from a drier hot spring to a cooler moist summer climate involves large transformations of the diurnal cycle, even within the monsoon season, which significantly affect both thermodynamical, dynamical and radiative fields. These results are believed to hold for the whole Northern Sahel and provide valuable ground truth for assessing models over an area displaying a rich variety of surface atmosphere regimes.

This study is complemented by that of Frappard et al. (this issue), looking at the 
1 mesoscale rainfall regime over the Gourma site and the Niger site.

Depraetere et al. use a new method, referred to as the Average Synchronized Hyetograph, to analyze the kinematics and assess the spatial organization of sudanian rain patterns. They find that $55 \%$ of rain events show the signature of a Mesoscale Convective System (MCS) and have similar characteristics to MCSs in the Sahel. Their results, which draw data from a rain gauge network, are consistent with results derived from satellite tracking and from radar.

\section{Vegetation}

Surprisingly few studies investigate the long-term response of vegetation to climate in West Africa, which severely impairs the understanding of ecosystem-climate interactions. As a result, modelling studies usually do not converge. The fundamentals of the Sahelian ecosystem dynamics and the response to the severe droughts of $70^{\prime}$ and $80^{\prime}$ are still a matter of debate, especially since human impact and land use combine with rainfall variability in shaping plants behaviour. Hiernaux et al. (this issue, b) document the response of Sahelian trees to the Sahelian drought across a rainfall, edaphic and grazing gradient in the Gourma based on a long-term dataset covering 1984-2006. They were able to show how recruitment took place after the strong mortality following the 1984 drought and to detail how soil type impacted tree mortality, which occurred sooner after drought in shallow soils and with a lag of a year or two on flooded clay soils. Time-constant of tree dynamics is indeed a key to possible inter-annual memory effect in surface-atmosphere interactions (Zeng et al. 1999). At a shorter time-scale, Seghieri et al. (this issue) investigate the phenology of trees, comparing sites in the Gourma and in the Benin sites of AMMA. Beside the ecological significance of the relationships between flowering, fruiting and environmental factors, their study provides clues to the control of evaporation by trees, which depends on both soil moisture availability and leaf unfolding. Averaging seven dominant species at each site, they found that maximum 
1 leafing largely precedes the water cycle in Benin and less so in the Sahel, with a clearer

2 relationship to soil moisture than to rainfall. Last, Hiernaux et al. (this issue, c) address the

3 question of herbaceous productivity response to climate variability and grazing pressure. In

4 addition to quantifying the response of productivity to the drought, they present evidence of a

5 decadal trend in floristic composition. The impact of grazing on the Sahelian ecosystems has

6 been and still is highly controversial, mostly because of the lack of adequate dataset. Hiernaux

7 et al. (this issue, c) were able to diagnose opposite effects of grazing, either decreasing or increasing productivity depending on the floristic composition, which was also impacted by grazing. In combination with the surface fluxes studies, these contributions provide the necessary bases for a realistic long term analysis of the possible feedbacks of vegetation changes on the atmosphere dynamics within the West African monsoon.

12

\section{Surface fluxes and Energy Budgets}

The surface-atmosphere exchange (flux) of momentum, heat, water, and carbon dioxide are the most important pathways through which biospheric processes can influence and interact with atmospheric boundary layer processes and thus monsoonal dynamics. Exchanges of momentum, heat and water, in particular, influence atmospheric stability, humidity and convective processes and thus the potential for the land surface to impact both cloud formation and rainfall. Heat and water fluxes, and thus energy partitioning, are also intimately coupled with carbon dioxide fluxes where, at short time-scales, water and carbon dioxide exchange is mediated by leaf-level stomatal conductance, and at longer time-scales, water exchange depends on antecedent carbon dioxide exchange, vegetation growth and leaf area.

Timouk et al. (this issue), highlight the large spatial variability in the seasonal cycles of net radiation and sensible heat flux within the Malian Gourma site, associated with variations 
1 in vegetation and water regime, which in turn depend on lateral water redistribution. Using a

2 simple upscaling scheme, they show that the landscape-scale sensible heat flux behaves

3 similarly to point-scale flux measured at the grassland site and provides fluxes at the scale of

4 atmospheric models.

5 Two companion papers (Ramier et al., Boulain et al., this issue) provide new insights into the

6 local-scale interacting physical and biological processes in the cultivated Sahelian

7 environment of west Niger. An integrated, continuous monitoring of the water, energy,

8 carbon, and vegetation cycles at two sites representing the dominant, cultivated and semi-

9 natural, land-use/land-cover types, allows progress towards a better understanding of the

10 couplings between hydrologic, vegetation and atmospheric processes via energy and

11 biogeochemical cycles.

12 Two papers make use of data collected by a large aperture scintillometer (LAS) to derive 13 area-averaged sensible and latent heat fluxes. Ezzahar et al., describe a LAS experiment 14 during a two month period in Niger (and propose a methodology to interpret LAS 15 observations made over heterogeneous terrain spanning several vegetation types. It was 16 successfully implemented over the Wankama catchment, and compared favourably to eddy 17 covariance measurements in the various vegetation types.

18 The second LAS study took place during two seasonal cycles at the sudanian Benin site. Guyot et al. (this issue) combine LAS observations of sensible flux with the energy balance method to estimate hourly latent heat flux during a two-month period with isolated rain 21 events. Water balance verification suggests that rainfall inputs to the shallow soil trigger an 22 additional contribution to evapotranspiration, assumed to originate from the underlying water 23 table through tree-root uptake. 
1 The analysis of feedback effects between continental surfaces and the atmosphere is a key

2 element in the understanding of the WAM dynamics. Monitoring of surface parameters, in

3 particular soil moisture, is consequently essential. A ground network was thus designed to

4 document the temporal and spatial variability of soil moisture profiles over the three AMMA-

5 CATCH sites. This network covers different vegetation types and climates. In the Sahel De

6 Rosnay et al. (this issue), use soil moisture measurements from the Gourma site to

7 characterise soil moisture at different spatial scales. They thus identify the critical spatial

8 scale needed to make soil moisture measurements that provide an accurate indication (low

9 variance and bias) of soil moisture dynamics at the scale of the super site. These relationships

10 are then used to evaluate the performance of microwave remote sensing data to assess surface

11 soil moisture in Sahelian areas where the vegetation is sparse (NDVI below 0.5) and does not

12 mask the soil signal. Zribi et al. (this issue), explore the capacity to monitor surface soil moisture of Sahelian sites in Niger and Mali at a $25 \mathrm{~km}$ resolution from passive microwave (ERS) data. The ERS products are evaluated against the AMMA campaign (2005-2006) ground and satellite data. They are then used to simulate the surface soil moisture over the 1992-2006 period. Differences between the northern and the southern Sahel are observed and can be related to precipitation cell size and to the very high evaporation rates in the northern regions, which lead to a rapid decrease in soil moisture following a precipitation event.

Pellarin et al. (this issue), demonstrates the feasibility to reproduce regional microwave land surface model / microwave model driven by a dense raingauge network as well as soil and vegetation information over a 120 by $100 \mathrm{~km}$ region near Niamey (Niger). In-situ observations from about 50 raingauges were essential to obtain accurate rainfall fields and to evaluate the simulation outputs at the local scale by comparison with soil moisture, evapotranspiration and runoff measurements. This study is a first step to perform large scale 
1 simulations driven by satellite rainfall fields and constrained by AMSR-E measurements.

2

\section{Hydrological processes and modeling}

Two complementary modelling approaches are used to improve the representation of the water cycle on the Niger site of the AC observing system. The first is a stochastic approach which aims at exploring how the data collected by the AC observing system may help in assessing the sensitivity of water cycle modelling to the resolution of the models forcing fields. The illustration given here is with regard to rainfall fields (Vischel et al., this issue); it builds on the wealth of previous hydrological studies at the Niger site, to put forward an innovative meso-scale model formulation for rainfields. The scope of the paper is to evaluate the potential for improved climate modelling via downscaling of coarse-scale rainfall data in terms of uncertainty assessment and bias reduction for runoff estimation.

3 The fully physical approach is illustrated by the paper of Saux-Picart et al performing a mesoscale modelling of the Sahelian land surface, based on field data collected at the AMMA-Niger site. They. apply a land surface model, which was adapted to the local environment, in order to spatialize water and energy fluxes over the ACN meso-site, with the help of input and validation data from remote sensing. 


\section{Concluding remarks}

2 The AMMA-CATCH observing system represents a unique infrastructure for long term

3 monitoring of land use / land cover and the associated hydrological cycle over an array of

4 three mesoscale sites sampling the eco-climatic gradient of West Africa. The observational and preliminary modelling results presented in this special issue essentially deal with the Sahelian sub-region. Several papers make use of datasets initiated in the 1980's and 1990's at the two Sahelian sites, providing a long term perspective on the evolution of climatic and environmental variables in a region under great climatic stress and demographic pressure. Other papers focus on the information brought by the additional sensors installed for the AMMA Enhanced Observing Period (EOP) in 2005. Even these shorter series of data prove to be a rich source of information on a region where the environment and the water cycle are poorly monitored by operational networks. First results from the Soudanian site observing system are also reported, but there is clearly a wealth of data that have yet to be analysed in order to provide a picture as detailed as the one obtained on the Sahelian sites. The challenge faced by our scientific community is clearly now to integrate and compare the results obtained on the three sites and to use this data set for integrated modelling studies of the coupled atmosphere - land surface - water cycle system in West Africa. One research direction of particular existence is the study of possible feedbacks of a changing environment and related water budget components on mesoscale and regional atmosphere dynamics; since land use changes remain strong and widespread in this region, feedback effects, if proven, should be taken into account in land management not only from the perspective of its direct impact on resources available to the populations but also as a factor influencing the rainfall regime. Clarifying this issue at the regional scale would be a great contribution to Earth System

24 Science, whose goal is precisely to observe, understand and predict global environmental changes involving interactions between land, atmosphere, water, biosphere, societies, 
1 technologies and economies. This goal is reachable only through long term monitoring and

2 modelling strategies on regional systems such as West Africa.

3 An important issue for the future is the possibility of maintaining such an observing system 4 beyond the present decade. This will first require a greater involvement of the African scientific community who often lack the financial resources enabling them to participate in intensive field work or use and develop the point, regional and global models that benefit from such field measurements. African scientists have a vested and deep scientific interested in studying the impact of climate and land cover changes on water resources, agriculture, health, social and economic developments in West Africa. Increasing opportunities for involvement should be a significant part of the AMMA-CATCH strategy for the years to come. Another important point is to work on a better integration between the ground observing strategy of AMMA-CATCH and satellite missions. Two missions are of special interest in this respect: the Soil Moisture and Ocean Salinity mission (SMOS) and the MeghaTropiques mission (MT), scheduled to be launched in 2009 and 2010 respectively. SMOS is devoted to soil moisture monitoring using a 2D L-Band $(1.4 \mathrm{GHz})$ interferometer equipped with a synthetic aperture antenna. MT is focused on the tropical atmospheric water cycle with a strong emphasis on rainfall and estimation of the radiative budget at the top of the tropical atmosphere. Using these new satellite data along with those of the AQUA Train and MSG in conjunction with the ground AMMA-CATCH data is an exciting perspective for all the scientists involved in the science of the Earth System in West Africa.

\section{Acknowledgments}

Based on a French initiative, AMMA was built by an international scientific group and is currently funded by a large number of agencies, especially from France, the UK, the US and Africa. It has been the beneficiary of a major financial contribution from the European Community's Sixth Framework Research Programme. Detailed information on scientific coordination and funding is available on the AMMA International website http://www.ammainternational.org. The AMMA-CATCH observing system has been funded since 2001 by IRD, INSU and the French Ministry of Research. The National Center for Atmospheric Research is sponsored by the National Science Foundation 


\section{References}

AMMA-ISSC, 2005. The International Science Plan for AMMA, http://amma-international.org/ library/docs/AMMA_ISP_May2005.pdf, 103 p.

AMMA-ICIG, 2006. International Implementation Plan. http://amma-international.org/ implementation/docs/IIP v3.0.pdf, 393 p.

Anyamba, A. and Tucker, C.J., 2005. Analysis of Sahelian vegetation dynamics using NOAAAVHRR NDVI data from 1981-2003. Journal of Arid Environments 63(3), 596-614.

Balme M., Galle S. and Lebel T., 2005. Démarrage de la saison des pluies au Sahel : variabilité à des échelles hydrologique et agronomique. Sécheresse 16 (1), 15-22.

Boulain, N., Cappelaere, B., Ramier, D., Bil-Assanou, I.H., Halilou, O., Seghieri, J., Guillemin, F., Gignoux, J., Timouk, F., this issue. Towards an understanding of coupled physical and biological processes in cultivated Sahel - 2. vegetation and carbon dynamics. Journal of Hydrology this issue.

Braud I, Bessemoulin P, Monteny B, Sicot M, Vandervaere JP, Vauclin M, 1997. Unidimensional modelling of a fallow savannah during the HAPEX-Sahel experiment using the SiSPAT model. Journal of Hydrology 189 (1-4), 912-945.

Cappelaere B., Descroix L., Lebel T., Boulain N., Ramier D., Laurent J.-P., Le Breton E., Mamadou I., Boubkraoui S., Bouzou Moussa I., Favreau G., Issoufou H.B.A., Nazoumou Y., Quantin G., Chaffard V., Ottlé C., 2009. The AMMA-Catch experiment in the cultivated Sahelian area of south-west Niger - Strategy, implementation, site description, main results. Journal of Hydrology this issue

Casenave A., Valentin C., 1992. A runoff capability classification system based on surface features criteria in semi-arid areas of West Africa. Journal of Hydrology, 130: 231- 249.

Charney, J. G., 1975. Dynamics of deserts and drought in the Sahel. Quart. J. Roy. Met. Soc. 101(428), 193-202.

Davidson, O., Halsnæs, K., Huq, S., Kok, M., Metz, B., Sokona, Y., Verhagen, J., 2003. The development and climate nexus: the case of sub-Saharan Africa. Climate Policy 3S1, S97-S113.

Depraetere, C. et al., this issue. The organization and kinematics of tropical rainfall systems ground tracked at mesoscale with gages: First results from the campaigns 1999-2006 on the Upper Ouémé Valley (Benin). Journal of Hydrology this issue.

de Rosnay, P., Gruhier, C., Timouk, F., Baup, F., Mougin, E., Hiernaux, P., Kergoat, L., Le Dantec, V., this issue. Multi-scale soil moisture measurements over the Gourma meso-scale site in Mali. Journal of Hydrology this issue.

Descroix et al., this issue. Spatio-Temporal Variability of Hydrological Regimes Around the 
Boundaries between Sahelian and Sudanian Areas of West Africa: A Synthesis. Journal of Hydrology this issue.

Desconnets J.C., Taupin, J.D., Lebel T., Leduc C., 1997. Hydrology of the HAPEX-Sahel central Super-Site: surface water drainage and aquifer recharge through the pool systems. Journal of Hydrology 188-189, 155-178.

Dolman, A.J., Culf, A.D., Bessemoulin, P., 1997a. Observations of boundary layer development during the Hapex-Sahel intensive observation period. Journal of Hydrology 188-189, 998, 1016.

Dolman, A.J., Gash, J.H.C., Goutorbe, J.-P., Kerr, Y., Lebel, T., Prince, S.D., Stricker, J.N.M., 1997b. The role of land Surface in Sahelian climate: HAPEX-Sahel results and future research needs. Journal of Hydrology 188-189, 1067-1079.

Douville, H., Chauvin, F., Broqua, H., 2001. Influence of soil moisture on the Asian and African monsoons. Part I: mean monsoon and daily precipitation. Journal of Climate 14, 2381-2403.

Douville, H., 2002. Influence of soil moisture on the Asian and African monsoons. Part II: interannual variability. Journal of Climate 15, 701-720.

ECOWAS-SWAC, 2006. The Ecologically vulnerable zone of Sahelian countries. Atlas on Regional Integration in West Africa, http://www.atlas-ouestafrique.org/spip.php?rubrique43.

Eltahir, E.A.B., Gong, C., 1996. Dynamics of wet and dry years in West Africa. J. Clim 9, 1030-1042.

Ezzahar, J. Chehbouni, A., Hoedjes, J.C., Ramier, D., Boulain, N., Boubkraoui, S., Cappelaere, B., Descroix, L., Mougenot, B. and Timouk, F. this issue. Combining scintillometer and an aggregation scheme to estimate area-averaged latent heat flux during AMMA experiment. Journal of Hydrology this issue.

Favreau G, Cappelaere B, Massuel S, Leblanc M, Boucher M, Boulain N, Leduc C (2008), Land clearing, climate variability and water resources increase in semiarid southwest Niger, Africa : A review. Water resources Research (sous presse)

Fontaine, B., N. Philippon, and P. Camberlin, 1999: An improvement of June-September rainfall forecasting in the Sahel based upon region April-May moist static energy content (1968-1997). Geophysical Research Letters, 26(14), 2041-2044.

Frappart F., E. Mougin, F. Guichard, L. Kergoat, P. Hiernaux, M. Arjounin, F. Lavenu, T. Lebel, 2009. Rainfall regime over the Sahelian climate gradient in the Gourma. Journal of Hydrology this issue

Gash et al., 1997. The variability of evaporation during the HAPEX-Sahel intensive observation period. Journal of Hydrology 188-189, 385-399

Gaze, S.R., Simmonds, L.P., Brouwer, J., Bouma, J., 1997. Measurements of surface redistribution of rainfall and modelling its effect on water balance calculations of a millet field on sandy soil in Niger. Journal of Hydrology 188-189, 267-284 
Goutorbe, J.-P., 1994. HAPEX-SAHEL : a large-scale study of land-atmosphere interactions in the semi-arid tropics. Annales. Geophysicae 12, 53-64.

Goutorbe, J.-P. et al., 1997a. An overview of HAPEX-SAHEL: a study in climate and desertification. Journal of Hydrology 188-189, 4-17.

Goutorbe, J.-P., Noilhan, J., Lacarrere, P., Braud, I., 1997b.Modelling of the atmospheric water column over the central sites during HAPEX-Sahel. Journal of Hydrology 188-189, 998-1016.

Guengant, J.-P., Banoin, M., 2003. Dynamique des populations, disponibilités en terres et adaptation des régimes fonciers: le cas du Niger. Rome (ITA), Paris : FAO, CICRED, 144 p.

Guichard, F., Kergoat, L., Mougin, Timouk, F., Baup, F., Lavenu, F., this issue. Surface thermodynamics and radiative budget in the Sahelian Gourma, Part I: seasonal and diurnal cycles. Journal of Hydrology this issue.

Guyot, A., Cohard, J.-M., Anquetin, S., Galle, S., this issue. Combined analysis of energy and water budgets to consolidate latent heat flux estimation using an infrared scintillometer. Journal of Hydrology this issue.

Herrmann, S.M., Anyamba, A. and Tucker, C.J., 2005. Recent trends in vegetation dynamics in the African Sahel and their relationship to climate. Global Environmental Change 15, 394-404.

Herrmann, S.M. and Hutchinson, C.F., 2005. The changing contexts of the desertification debate. Journal of Arid Environments 63(3), 538-555.

Hiernaux, P., Ayantunde, A., Gérard, B., Grippa, M., Mougin, E., this issue (a). Resilience and productivity trends of crops, fallows and rangelands in Southwest Niger: impact of land use, management and climate changes. Journal of Hydrology this issue

Hiernaux, P., Diarra, L., Trichon, V., Baup, F., Soumaguel, N., Mougin, E., this issue (b). Woody plant population dynamics in response to climate changes from 1984 to 2006 in Sahel (Gourma,

\section{Mali). Journal of Hydrology this issue}

Hiernaux, P., Mougin, E., Diarra, L., Soumaguel, N., Lavenu, F., Tracol, Y., this issue (c). Sahelian rangeland response to changes in rainfall over two decades in the Gourma region, Mali. Journal of Hydrology this issue

Janicot, S., 1992: Spatiotemporal variability of West African rainfall. Part I: Regionalizations and Typings. J. Clim, 5, 489-511

Kabat, P., Dolman, A.J., Elbers, J.A.. 1997. Evaporation, sensible heat and canopy conductance of fallow savannah and patterned woodland in the Sahel. Journal of Hydrology 188-189, 494-515

Koster, R. D., Dirmeyer, P. A., Guo, Z., Bonan, G., Chan, E., Cox, P., Gordon, C. T., Kanae, S., Kowalczyk, E., Lawrence, D., Liu, P., Lu, C.-H., Malyshev, S., McAvaney, B., Mitchell, K., Mocko, D., Oki, T., Oleson, K., Pitman, A., Sud, Y.C., Taylor, C.M., Verseghy, D., Vasic, R., Xue, Y., Yamada, T., 2004. Regions of strong coupling between soil moisture and precipitation. 
Science 305: 1138-1140 [DOI: 10.1126/science.1100217].

Laval, K., Picon, L., 1986. Effects of a change in the surface albedo in the Sahel on climate. Journal of Atmospheric Sciences 43, 2418-2429.

Le Barbé, L., Lebel, T., 1997. Rainfall climatology of the HAPEX-Sahel region during the years 1950-1990. Journal of Hydrology 188-189, 43-73.

Le Barbé, L., Lebel, T., Tapsoba, D., 2002. Rainfall variability in West Africa during the years 19501990. J. Climate 15(2), 187-202.

Lebel, T., Taupin, J.D., D'Amato, N., 1997. Rainfall monitoring during HAPEX-Sahel: 1. General rainfall conditions and climatology. Journal of Hydrology 188-189, 74-96.

Lebel, T., A. Ali, this issue. Recent trends in the Central and Western Sahel rainfall regime (1990 2007). J. Hydrol., this issue.

Leduc, C., Favreau, G., Schroeter, P., 2001. Long term rise in a Sahelian water-table: the Continental Terminal in South-West Niger. Journal of Hydrology 243, 43-54.

Massuel, S., 2005. Recent trend in water resource response to climatic and environmental changes in South-western Niger. Runoff and groundwater modelling of the "kori de Dantiandou" basin over the period 1992-2003. Ph.D dissertation, Université Montpellier II, July 2005, 220 p.

Moncrieff, J.B. et al., 1997. Spatial and temporal variations in net carbon flux during HAPEX-Sahel. Journal of Hydrology 188-189, 563-588.

Mougin, E., Hiernaux, P., Kergoat, L. et al., this issue. Gourma site paper. The AMMA-CATCH Gourma observatory site in Mali: Relating climatic variations to changes in vegetation, surface hydrology, fluxes and natural resources.

Nicholson, SE. 1980. The nature of rainfall fluctuations in subtropical West-Africa. Mon. Wea. Rev. 109, 2191-2208.

Nicholson, SE., 2000. Land Surface processes and Sahel climate. Reviews of Geophysics. 38(1), $117-$ 139.

Nicholson, S., 2005. On the question of the "recovery" of the rains in the West African Sahel. Journal of Arid Environments 63(3), 615-641.

Olsson, L., Eklundh, L. and Ardo, J., 2005. A recent greening of the Sahel - Trends, patterns and potential causes. Journal of Arid Environments 63(3), 556-566.

Pellarin, T., Laurent, J.-P., Decharme, B., Descroix, L., Cappelaere, B., this issue. Hydrological modelling and associated microwave emission of a semi-arid region in South-western Niger. Journal of Hydrology this issue.

Peugeot, C., Esteves, M., Galle, S., Rajot, J.L., Vandervaere, J.P., 1997. Runoff generation processes: results and analysis of field data collected at the East Central Supersite of the HAPEX-Sahel 
experiment. Journal of Hydrology 188-189(1-4), 179-202.

Peugeot, C., Cappelaere, B., Vieux B., Séguis L., and Maia-Bresson A., 2003. Hydrologic process simulation of a semiarid, endoreic catchment in Sahelian West Niger. 1. Model-aided data analysis and screening. Journal of Hydrology, 279, 224-243. Philippon N., Fontaine, B., 2001. The relationship between the Sahelian and previous second Guinean rainy seasons: a monsoon regulation by soil wetness, Annales Geophysicae 20(4), 575-582.

Polcher, J., 1995: Sensitivity of tropical convection to land surface processes. Journal of Atmospheric Sciences, 52, 3143-3161.

Prince, S.D., Brown de Coulston, E. and Kravitz, L.L., 1998. Evidence from rain-use efficiencies does not indicate extensive Sahelian desertification. Global Change Biology 4(4), 359-374.

Redelsperger, J.-L., Thorncroft, C., Diedhiou, A., Lebel, T., Parker, D., Polcher, J., 2006. African Monsoon, Multidisciplinary Analysis (AMMA): An International Research Project and Field Campaign. Bulletin of the American Meteorological Society 87(12), 1739-1746.

Ramier, D. et al., this issue. Towards an understanding of coupled physical and biological processes in the cultivated Sahel - 1. energy and water. Journal of Hydrology this issue.

Rowell, D.P., Folland, C.K., Maskell, K., Ward, M.N., 1995. Variability of summer rainfall over tropical north Africa (1906-92): Observations and modelling. Q.J.R. Meteorol. Soc. 121, 669-704.

Said,F., Attié, J.L., Bénech, B., Druilhet, A., Durand, P., Marciniak, M.H., Montenya, B., 1997. Spatial variability in airborne surface flux measurements during HAPEX-Sahel. Journal of Hydrology 188-189, 878-911.

Saux-Picart, S., Ottlé, C., Decharme, B., André, C., Zribi, M., Perrier, A., Coudert, B., Boulain, N., Cappelaere, B., this issue. Water and Energy budgets simulation over the Niger super site spatially constrained with remote sensing data. Journal of Hydrology this issue.

Seghieri, J. et al., this issue. Relationships between climate, soil moisture and phenology of the woody cover in two sites located along the West African latitudinal gradient. Journal of Hydrology this issue.

Simioni, G., Gignoux, J., Le Roux, X., 2003. Tree layer spatial structure can affect savanna production and water budget: Results of a 3-D model Ecology 84 (7), 1879-1894.

Miller, M., Slingo, A., 2007. The Arm Mobile Facility and Its First International Deployment: Measuring Radiative Flux Divergence in West Africa. Bulletin of the American Meteorological Society 88(8), 1229-1244.

Stige, L.C., Stave, J.; Chan, K.S., Ciannelli, L., Pretorelli, N., Glantz, P., Herren, H.R., Stenseth, N.C., 2006. The effect of climate variation on agro-pastoral production in Africa. Proceedings of the National Academy of Sciences USA 103, 3049-3053.

Taylor, C., Lebel, T., 1998. Observational evidence of persistent convective scale rainfall patterns. 
Monthly Weather Review 126, 1597-1607.

2

Taylor, C., Parker, D., Harris, P, 2007 An observational case study of mesoscale atmospheric

3

4

5

6

7

8

9

10

12

13

14

15

16

17

circulations induced by soil moisture. Geophysical Research Letters 34 (L15801), doi:10.1029/2007GL030572.

Timouk, F. Kergoat L., Mougin E., Lloyd C., Ceschia E., de Rosnay P., Hiernaux P., Demarez V., Taylor, C.M., this issue. Response of sensible heat flux to water regime and vegetation development in a central Sahelian landscape. Journal of Hydrology this issue.

Vischel, T. Lebel, T., Massuel, S., Cappelaere, B. this issue. Conditional simulation schemes of rain fields and their application for rainfall runoff modeling studies in the Sahel. Journal of Hydrology this issue.

Xue and Shukla, 1993. The influence of land surface properties on Sahel climate. Part I: Desertification. J. Climate, 6, 2232-2245.

Zeng N., J.D. Neeling, K.M. Lau and C.J. Tucker (1999), Enhancement of Interdecadal Climate Variability in the Sahel by Vegetation Interaction, Science, 286, 5444, 1537 - 1540.

Zribi, M. et al., this issue. ERS Scatterometer surface soil moisture analysis of two sites in the south and north of the Sahel region of West Africa. Journal of Hydrology this issue. 


\author{
T. Lebel et al.
} an overview.

\author{
T. Lebel et at.
} \\ List of FIGURES
}

Figure 1. Map of the mean annual rainfall difference between the period 1951-1970 and the period 1971-1990. Heavy closed contours indicate the position of the AMMA-CATCH meso-sites

Figure 1. Time series of the standardized precipitation index for a) a Sahelian box and b) a Soudanian box.

Figure 3. Distribution of population in West Africa (2003). The most populated zones are the coastal region and the cultivated Sahel. Red-orange and blue-green colors indicate densely versus sparsely populated areas, respectively.

Figure 4: Map of the dimensionless factor describing the impact of soil moisture on precipitation in the average of 12 climate models participating. Insets: Areally averaged coupling strengths for the 12 individual models over the outlined, representative hotspot regions. From Koster et al., 2004.

Figure 5: Yearly groundwater storage versus rainfall for the Kori-Dantiandou catchment $(\sim 5000$ $\mathrm{km}^{2}$ ) from 1992 to 2005. The ground water recharge was computed from a model developed by Massuel, 2005.

Figure 6: Increase of the yearly groundwater recharge due to vegetation changes between 1950 and 2000.

Figure 7: Time series of the annual rainfall (mm) on the AMMA-CATCH Niger (ACN) site versus the corresponding number of Mesoscale rain events as determined from the ground network (left) and versus the mean event rainfall in mm (right). Also shown on the left graph, is the annual rainfall produced by the mesoscale rain events only

Figure 8: The AMMA-CATCH long term monitoring meso-sites. Each site is equipped with an array of hydrological sensors and vegetation monitoring sites (see Descroix et al., and Mougin et al., this issue, for details). Also shown in the map are the radio-sounding stations operated by ASECNA (Agence pour la Sécurité de la Navigation Aérienne), providing the upper air information required to link the surface processes documented on the AMMA-CATCH meso-sites with the meteorological forcing. 


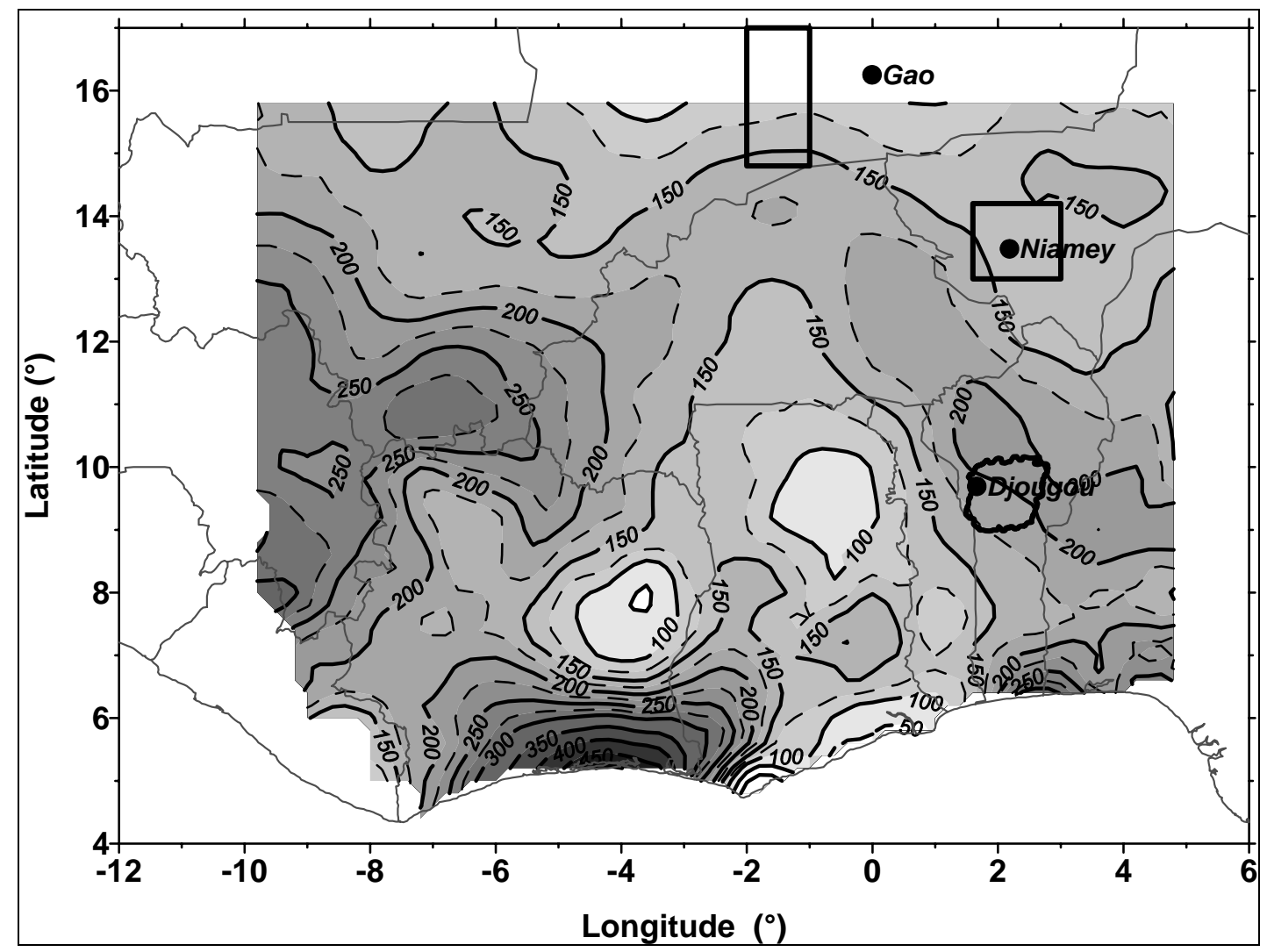

Figure 1. Map of the mean annual rainfall difference between the period 1950-1969 and the period 1970-1989. Heavy contours indicate the location of the three AMMA-CATCH meso-sites. Country borders are shown in light grey (see also Fig. 8 for a larger scale map of the AMMA-CATCH mesosites).

\section{a. Central Sahel $\left(10^{\circ} \mathrm{W}-10^{\circ} \mathrm{E} ; 11^{\circ} \mathrm{N}-17^{\circ} \mathrm{N}\right)$}

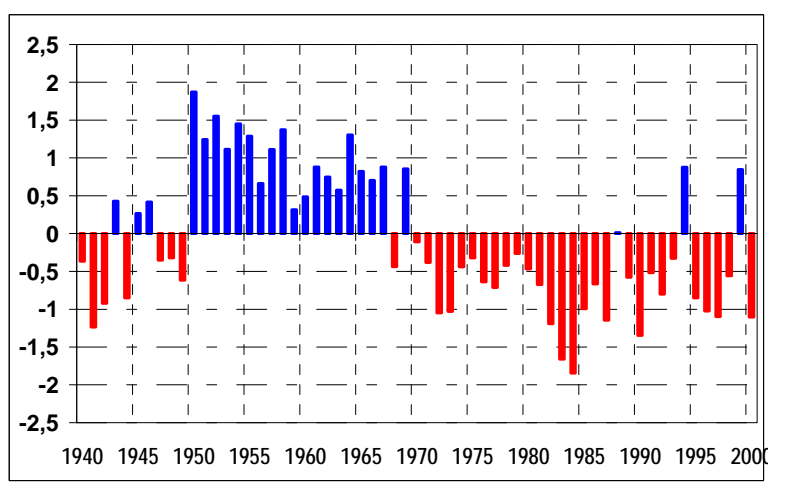

\section{b. Benin \& Togo $\left(0^{\circ}-4^{\circ} \mathrm{E} ; 6^{\circ} \mathrm{N}-11^{\circ} \mathrm{N}\right)$}

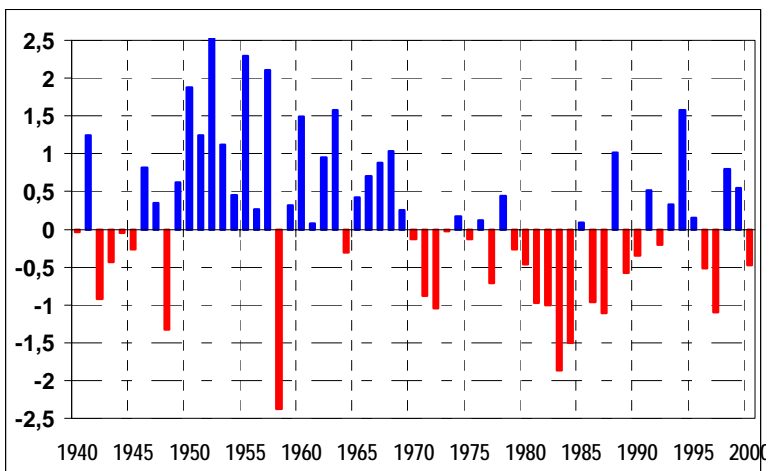

Figure 2. Time series of the standardized precipitation index for a) a region in the Sahel bioclimate zone and b) a region in the Soudanian bioclimate zone. 


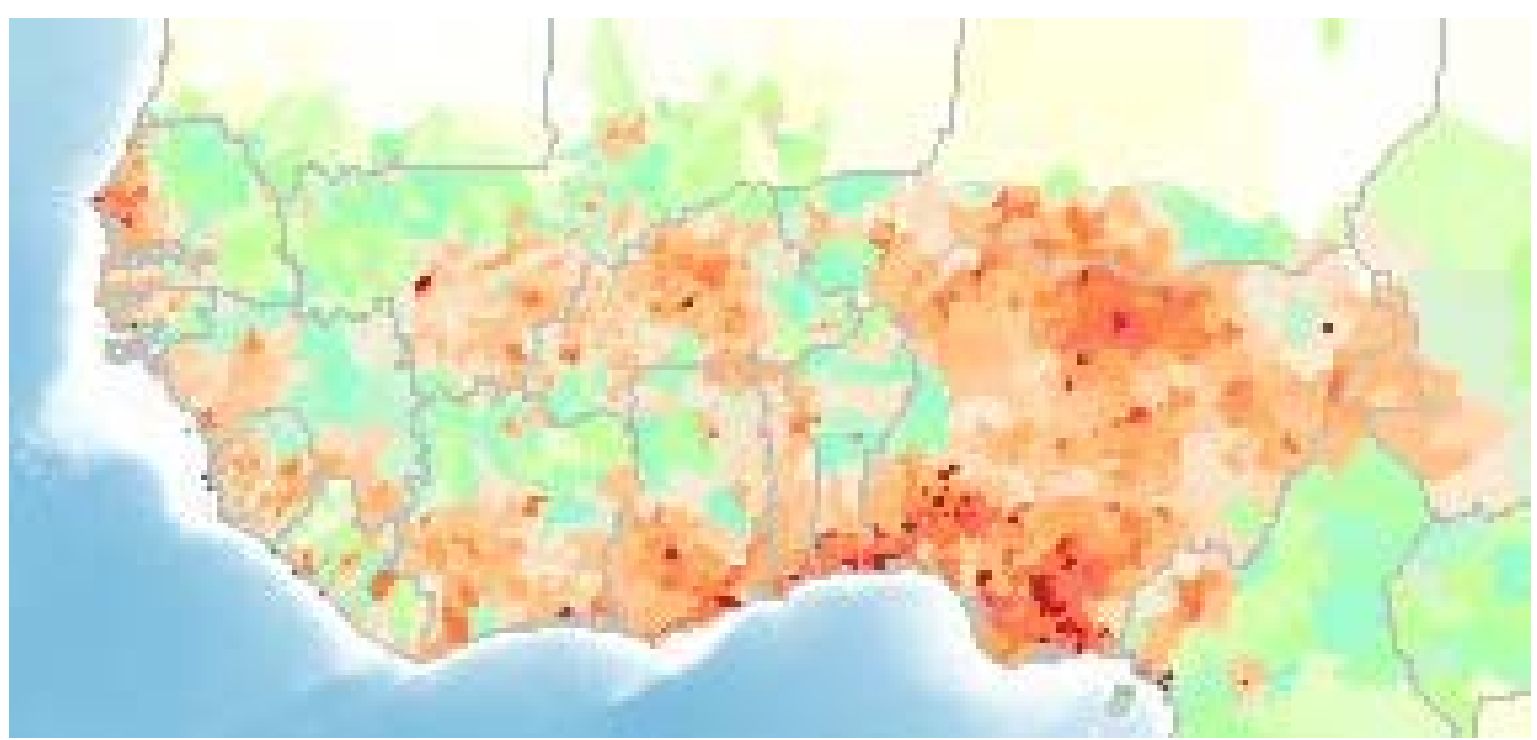

Figure 3. Distribution of population in West Africa (2003). The most populated zones are the coastal region and the cultivated Sahel. Red-orange and blue-green colors indicate densely versus sparsely populated areas, respectively.

\section{Land-atmosphere coupling strength (JJA), averaged across AGCMs}

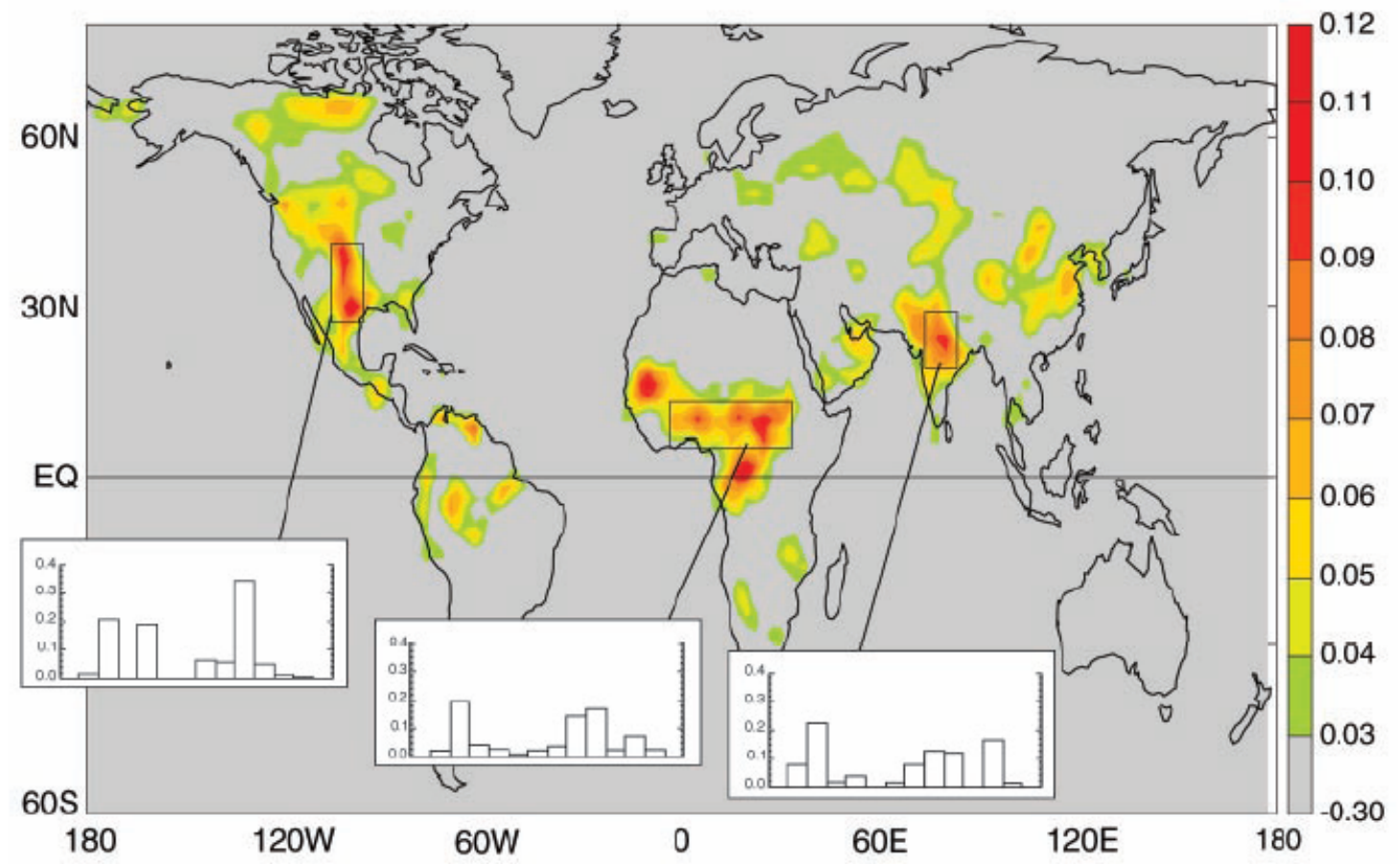

Figure 4. Map of the dimensionless factor describing the impact of soil moisture on precipitation in the average of 12 climate models participating. Insets: Areally averaged coupling strengths for the 12 individual models over the outlined, representative hotspot regions. From Koster et al., 2004. 


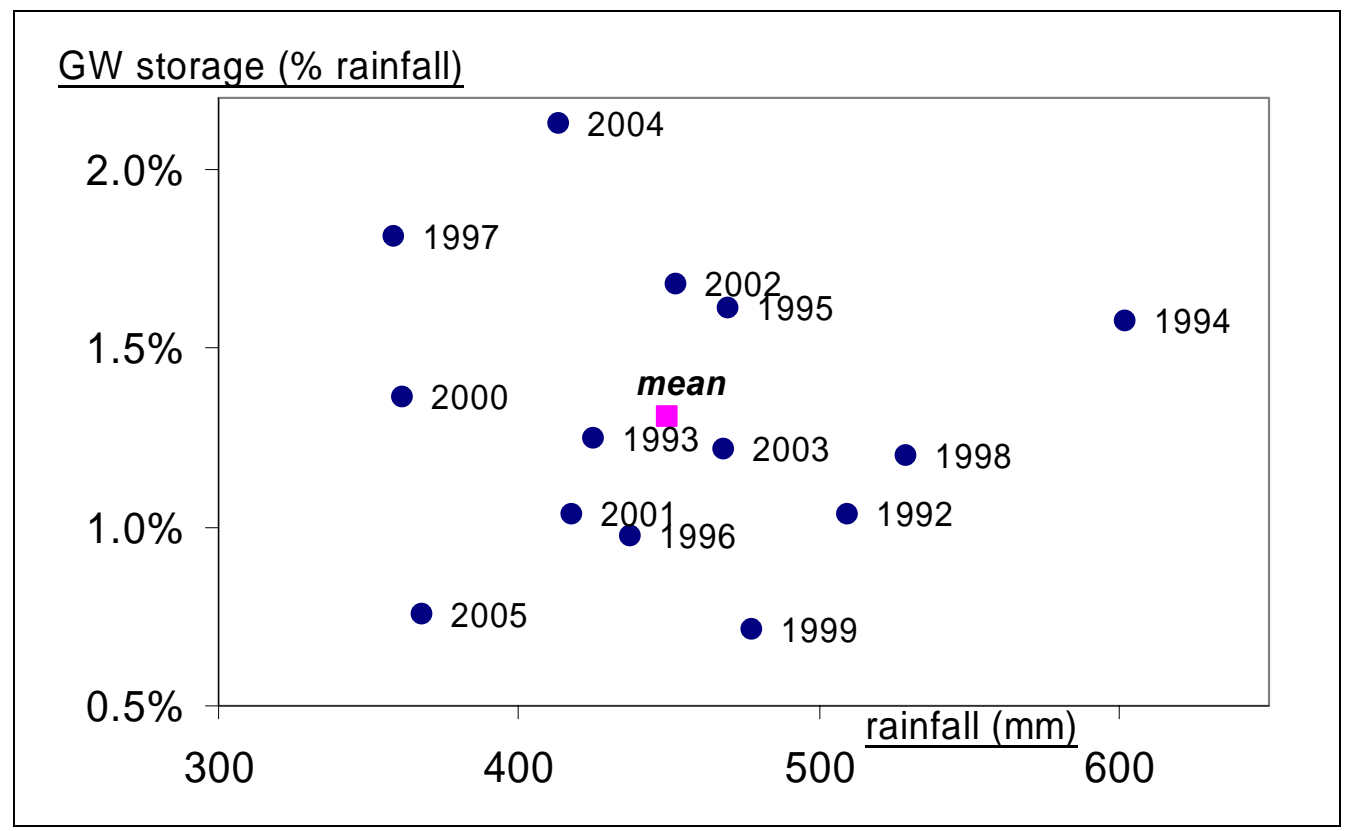

Figure 5. Yearly groundwater storage versus annual rainfall for the Kori-Dantiandou catchment ( $5000 \mathrm{~km}^{2}$ ) from 1992 to 2005. The ground water recharge was computed from a model developed by Massuel, 2005.

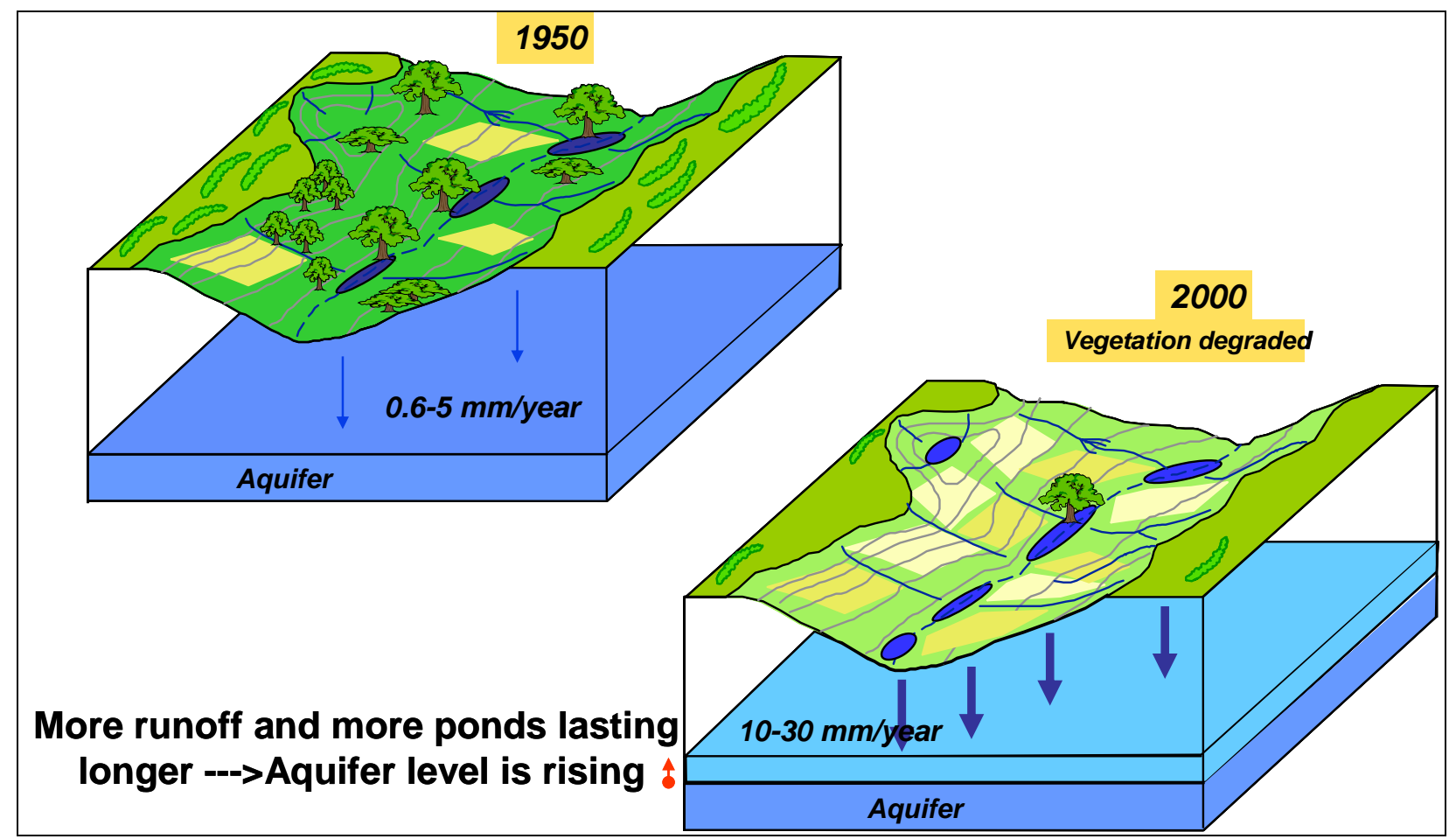

Figure 6. Increase of the yearly groundwater recharge due to vegetation changes between 1950 and 2000 (numbers from Favreau et al., 2002). 


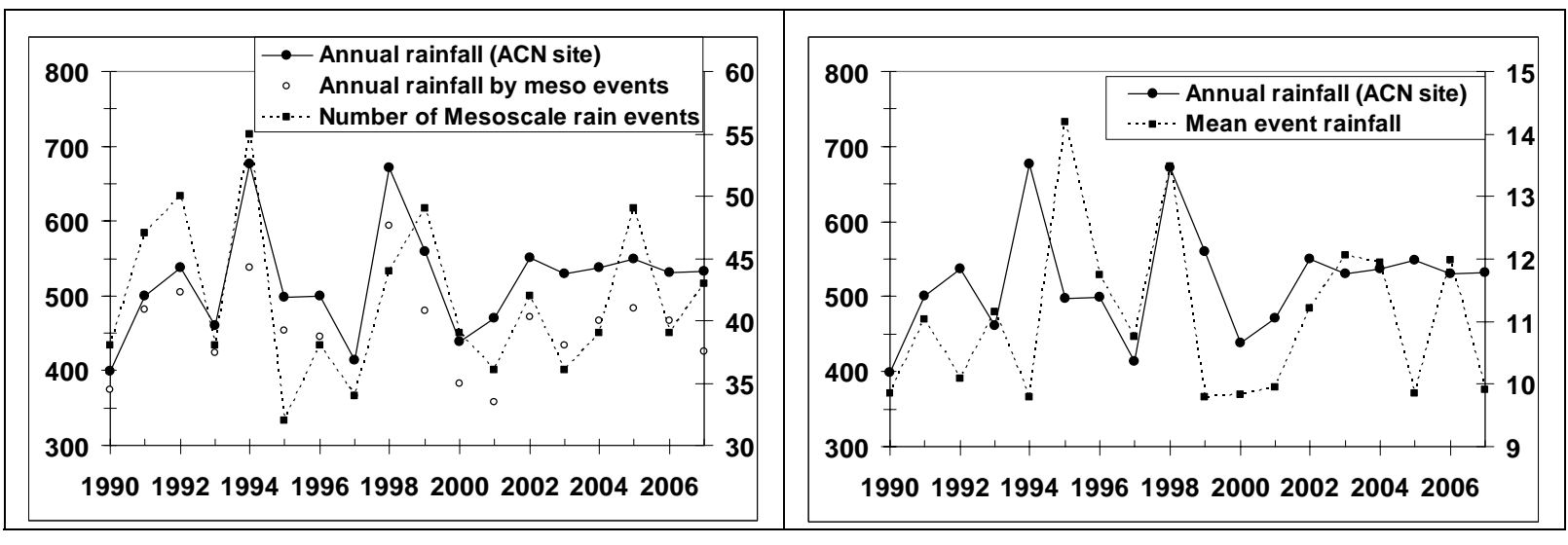

Figure 7. Time series of annual rainfall (mm) in the AMMA-CATCH Niger (ACN) site versus the corresponding number of Mesoscale rain events as determined from the ground network (left) and versus the mean event rainfall in mm (right). Also shown on the left graph, is the annual rainfall produced by the mesoscale rain events only.

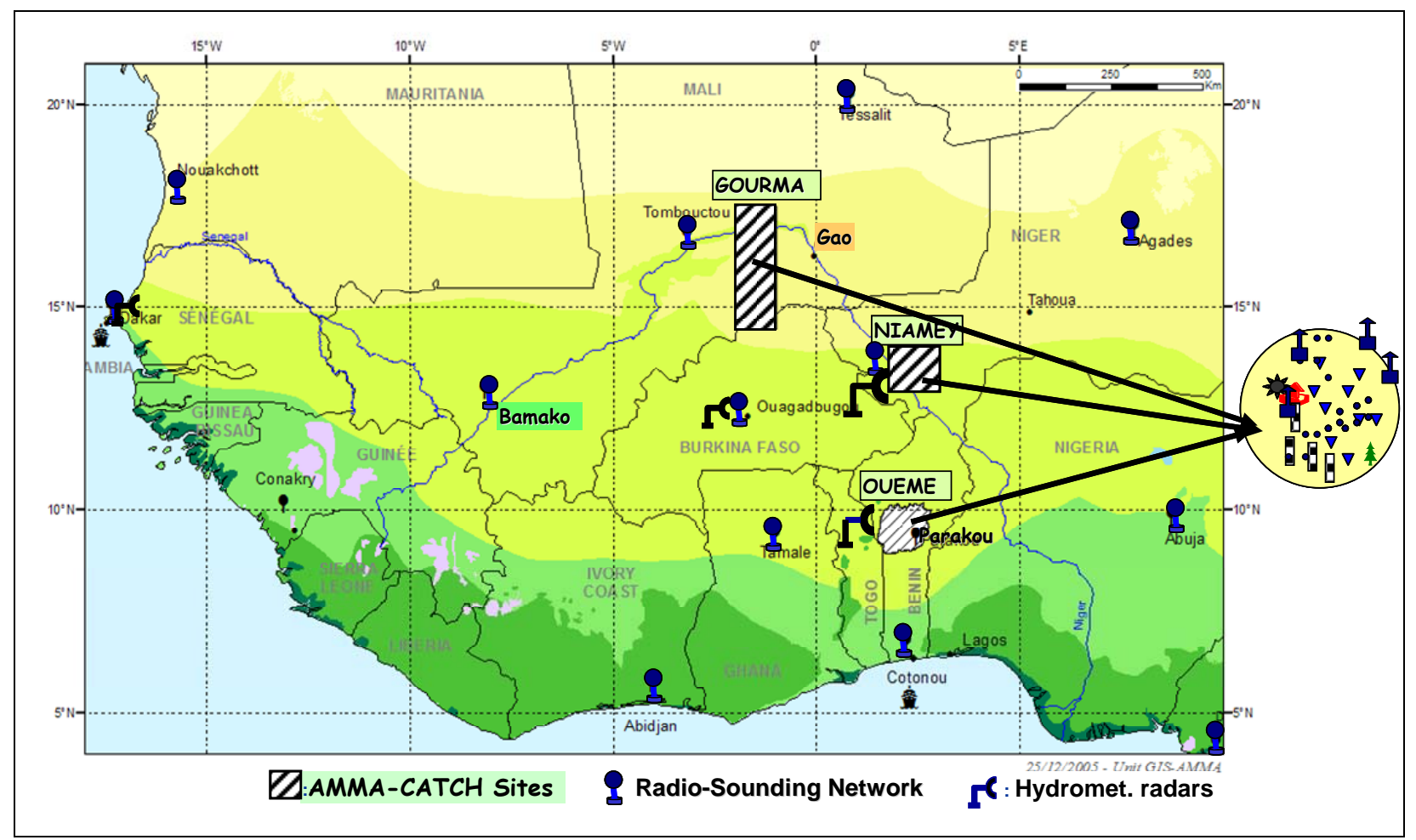

Figure 8. The AMMA-CATCH long term monitoring meso-sites. Each site is equipped with an array of hydrological sensors and vegetation monitoring sites (see Cappelaere et al., and Mougin et al., this issue, for details). Also shown on the map are the radio-sounding stations operated by ASECNA (Agence pour la Sécurité de la Navigation Aérienne), providing the upper air information required for linking the surface processes documented on the AMMA-CATCH meso-sites with the synoptic meteorological forcing. Symbols in the circle indicate networks of rain gauges, stream gauging stations, flux stations, vegetation monitoring parcels. 